\title{
Soil Carbon Storage by Switchgrass Grown for Bioenergy
}

\author{
M. A. Liebig • M. R. Schmer • K. P. Vogel • \\ R. B. Mitchell
}

Published online: 26 September 2008

(C) The Author(s) 2008. This article is published with open access at Springerlink.com

\begin{abstract}
Life-cycle assessments (LCAs) of switchgrass (Panicum virgatum L.) grown for bioenergy production require data on soil organic carbon (SOC) change and harvested $\mathrm{C}$ yields to accurately estimate net greenhouse gas (GHG) emissions. To date, nearly all information on SOC change under switchgrass has been based on modeled assumptions or small plot research, both of which do not take into account spatial variability within or across sites for an agro-ecoregion. To address this need, we measured change in SOC and harvested C yield for switchgrass fields on ten farms in the central and northern Great Plains, USA (930 km latitudinal range). Change in SOC was determined by collecting multiple soil samples in transects across the fields prior to planting switchgrass and again 5 years later after switchgrass had been grown and managed as a bioenergy crop. Harvested aboveground $\mathrm{C}$ averaged $2.5 \pm$ $0.7 \mathrm{Mg} \mathrm{C} \mathrm{ha}{ }^{-1}$ over the 5 year study. Across sites, SOC increased significantly at $0-30 \mathrm{~cm}(P=0.03)$ and $0-120 \mathrm{~cm}$ $(P=0.07)$, with accrual rates of 1.1 and $2.9 \mathrm{MgC}^{-1}$ year ${ }^{-1}$ (4.0 and $10.6 \mathrm{Mg} \mathrm{CO}_{2} \mathrm{ha}^{-1}$ year ${ }^{-1}$ ), respectively. Change in SOC across sites varied considerably, however, ranging from -0.6 to $4.3 \mathrm{Mg} \mathrm{C}^{-1}$ year $^{-1}$ for the $0-30 \mathrm{~cm}$ depth. Such variation in SOC change must be taken into
\end{abstract}

Electronic supplementary material The online version of this article (doi:10.1007/s12155-008-9019-5) contains supplementary material, which is available to authorized users.

M. A. Liebig $(\bowtie)$

Northern Great Plains Research Laboratory, USDA-ARS,

P.O. Box 459, Mandan, ND 58554, USA

e-mail: mark.liebig@ars.usda.gov

M. R. Schmer · K. P. Vogel • R. B. Mitchell

Grain, Forage, and Bioenergy Research Unit, USDA-ARS,

University of Nebraska,

P.O. Box 830737, Lincoln, NE 68583, USA consideration in LCAs. Net GHG emissions from bioenergy crops vary in space and time. Such variation, coupled with an increased reliance on agriculture for energy production, underscores the need for long-term environmental monitoring sites in major agro-ecoregions.

Keywords Bioenergy Carbon sequestration .

Greenhouse gas balance Perennial biofeedstocks .

Switchgrass
Abbreviations
GHG Greenhouse gas
LCAs Life-cycle assessments
SOC Soil organic carbon

\section{Introduction}

Environmental and social consequences associated with large-scale biofuel production from grain, sugar, and dedicated bioenergy crops are being critically examined $[16,30,36]$. Utilization of perennial herbaceous crops as biofuel sources has been purported to mitigate negative consequences due mainly to their lower requirements of fertilizers and pesticides relative to annual crops and their ability to be grown on marginal land $[16,36]$. Among the portfolio of herbaceous perennial crops considered for adoption throughout the USA, switchgrass (Panicum virgatum L.) has shown promise as a cellulosic ethanol source due to its high productivity across a large geographical domain [26]. Results from life-cycle assessments (LCAs) of switchgrass grown for bioenergy, however, have been mixed $[1,8,32,33]$, due in large part to the assigned net GHG emissions associated with switchgrass production and assumptions made in indirect land conversion costs. 
Net GHG emissions from switchgrass bioenergy production are inextricably linked to carbon dioxide uptake and subsequent sequestration in soil. Carbon sequestration by switchgrass has been nearly ubiquitous across a broad range of growing conditions throughout North America at rates of 1.7-10.1 Mg Cha ${ }^{-1}$ year $^{-1}$ (6.2-37.0 $\mathrm{Mg} \mathrm{CO}_{2} \mathrm{ha}^{-1}$ year $\left.^{-1}\right)$ [11, 13, 18, 45]. Nearly all measurements of soil organic carbon (SOC) change under switchgrass have been based on small plot research. While these assessments are useful, small plot research does not take into account spatial variability within or across farmer-managed fields. Furthermore, extension of results from small plot research to an agro-ecoregion is, at best, tenuous.

To obtain relevant, field-scale information for an agroecoregion, we sought to determine SOC change and harvested $\mathrm{C}$ yield within switchgrass fields on ten farms in the central and northern Great Plains, USA. Farms were located in Nebraska, South Dakota, and North Dakota, encompassing an area where previous modeling efforts have shown switchgrass production for bioenergy to be economically feasible [40]. Switchgrass fields included in the study were the focus of previously published net energy and economics analyses [29, 32].

\section{Methods}

\section{Experimental Sites}

Sites included in the study extended $930 \mathrm{~km}$ north to south and $230 \mathrm{~km}$ east to west within the Great Plains states of Nebraska, South Dakota, and North Dakota (Fig. 1). Major Land Resource Areas (MLRA) representative of study sites encompassed approximately 30 Mha and included 53B and $\mathrm{C}$ (Central and Southern Dark Brown Glaciated Plains), 55A, B, and C (Northern, Central, and Southern Black Glaciated Plains), 65 (Nebraska Sand Hills), 75 (Central Loess Plains), 102C (Loess Uplands), and 106 (Nebraska and Kansas Loess Drift Hills) [3]. Climate within the region is generally classified as semiarid to subhumid continental, with cold and dry winters, warm to hot summers, and erratic precipitation [3]. Mean annual precipitation for the study sites ranges from 432 to $777 \mathrm{~mm}$ increasing from west to east, while mean annual temperature ranges from $4.7^{\circ} \mathrm{C}$ in the north to $10.6^{\circ} \mathrm{C}$ in the south. Soils at the sites possessed high inherent fertility, with Ustolls and Udolls as the dominant taxonomic suborders [38] (Table 1).

Initial soil conditions at the ten sites were not limiting to switchgrass establishment and growth [see supplementary online material]. Medium textured soils were prevalent across the sites, with the exception of the soil at Atkinson, which was classified as sand. Values for soil bulk density across sites were below critical threshold values for restriction of root growth [17]. Soil $\mathrm{pH}$ across sites varied from strongly acid to moderately alkaline [37] (data not shown), and fell within a range for successful switchgrass germination [15].

Sites seeded to switchgrass were fields on working farms previously used for annual crop production. Field characteristics were such that they would have qualified for enrollment in the Conservation Reserve Program (CRP) [31]. Field size across sites averaged 6.7 ha (Range $=3.0$ to $9.5 \mathrm{ha}$ ). Sites at Douglas, Lawrence, and Crofton were seeded to switchgrass in 2000, while all other sites were seeded in 2001. Cultivars used for seeding included Cave-in-Rock (Douglas, Lawrence), Trailblazer (Douglas, Lawrence, Crofton, Atkinson, Huron, Highmore, Bristol), Shawnee (Lawrence, Crofton, Ethan), and Sunburst (Streeter, Munich). With the exception of Sunburst, all cultivars originated south of $43^{\circ} \mathrm{N}$ latitude [4]. Switchgrass was seeded at a rate of 322 pure live seeds (PLS) $\mathrm{m}^{-2}$, or approximately $10 \mathrm{~kg} \mathrm{ha}^{-1}$ using minimum or no-till management practices. Application of $\mathrm{N}$ varied in amount and type across sites based on biomass yield expectations and soil moisture conditions. Over the 5 year period of the switchgrass stands, site averages of applied $\mathrm{N}$ ranged from 31 to $104 \mathrm{~kg}$ $\mathrm{N}$ ha ${ }^{-1}$ year $^{-1}$ (Mean=74 $\mathrm{kg} \mathrm{N}^{-1}$ ). With the exception of the establishment year, aboveground biomass was harvested annually and baled. Most cooperating farmers harvested at emerged inflorescence to post-anthesis (early to mid-August) in post-establishment years. In contrast, farmers at Bristol, SD and Munich, ND harvested after a killing frost [32]. Biomass samples from switchgrass bales were used to determine dry matter and $\mathrm{C}$ concentration. Harvested $\mathrm{C}$ was determined by multiplying the biomass yield by the biomass $\mathrm{C}$ concentration. To verify machine harvested yields, aboveground biomass was hand-clipped, dried, and weighed from $1.1 \mathrm{~m}^{2}$ quadrants at 16 locations within each field [32]. Additional details on site establishment, management, and biomass harvest and analysis are outlined elsewhere [31, 32].

\section{Sampling Protocol}

To evaluate change in SOC under switchgrass over time, soil samples were collected from each site on a 5 year time-step. Sites in Nebraska were sampled in 2000 and 2005, while all other sites were sampled in 2001 and 2006. Samples were collected in the spring once soils were no longer frozen and surface conditions were dry enough to permit vehicular traffic. In 2000 and 2001, samples were collected immediately prior to switchgrass planting.

At each site, soil samples were collected from two transects with three sampling locations each (located approximately $30 \mathrm{~m}$ apart), resulting in a total of six sampling locations per site. Coordinates for each sampling location were recorded using a handheld GPS devise with an accuracy of $<3 \mathrm{~m}$ (Garmin International, Inc., Olathe, KS). Sampling locations were treated as pseudoreplicates as reviewed by Gomez [14]. 
Fig. 1 Sampling sites for evaluating change in soil organic carbon under switchgrass

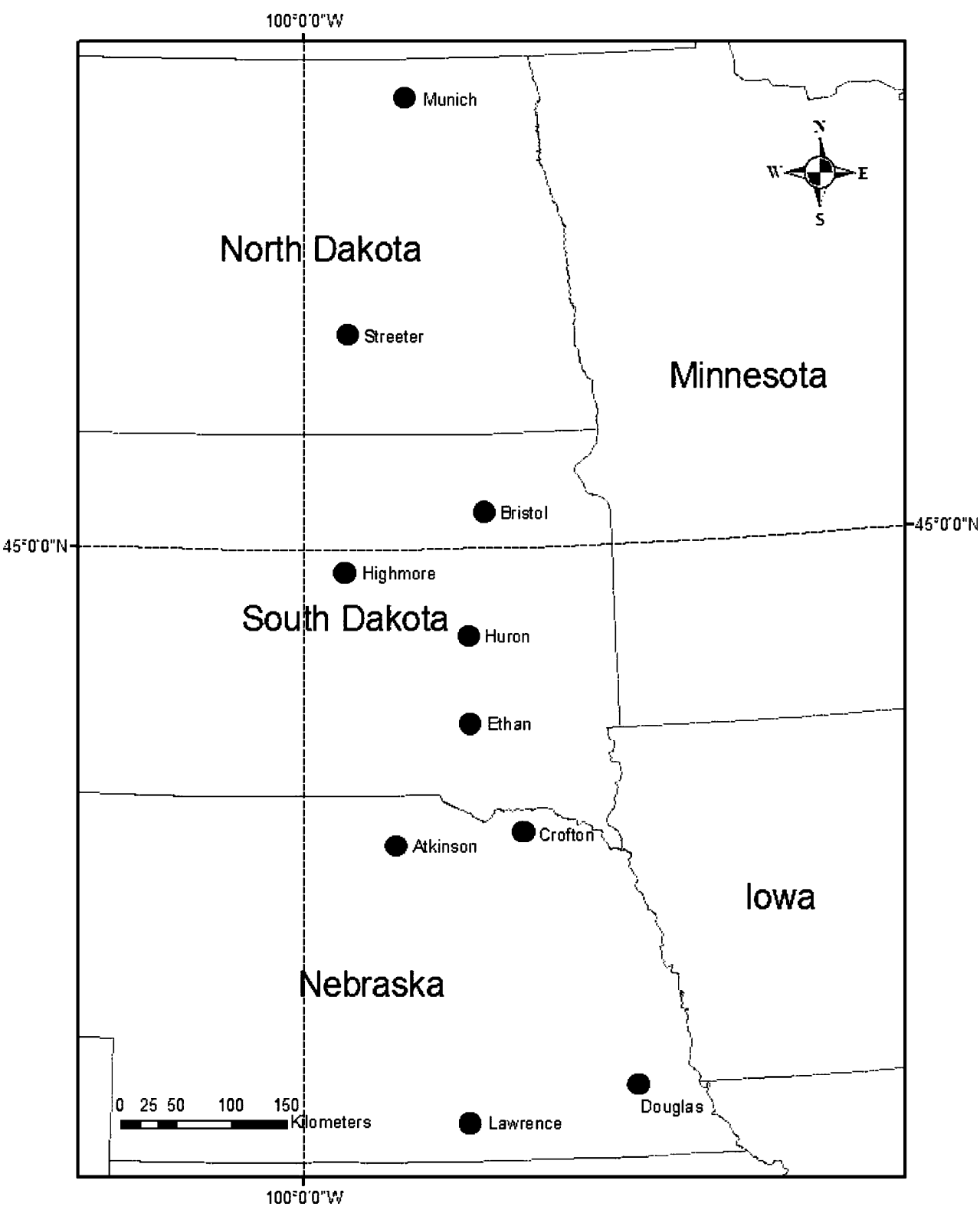

Due to difficulty during initial sample collection at Atkinson, only two locations per transect were sampled.

Soil samples were collected using a truck-mounted Giddings hydraulic probe (Giddings Machine Company, Windsor, CO, USA) with an inner tip diameter of 4.2 or $4.4 \mathrm{~cm}$, depending on soil conditions at the time of sampling. Soil depths sampled were 0-5, 5-10, 10-20, 20-30, 30-60, 60-90, and 90-120 cm for three Nebraska sites (Crofton, Douglas, Lawrence) and 0-5, 5-10, 10-20, and $20-30 \mathrm{~cm}$ for the remaining sites. To ensure adequate sample mass for laboratory analyses, seven soil cores were composited at each sampling location (approximately $1 \mathrm{~m}^{2}$ ) for the $0-5$ and 5-10 cm depths, five soil cores for the 1020 and $20-30 \mathrm{~cm}$ depths, and two soil cores for the 30-60, 60-90, and 90-120 cm depths. Following collection, each sample was saved in a double-lined plastic bag, stored in coolers while in transit to the laboratory, and then placed in cold storage at $5^{\circ} \mathrm{C}$ until processing.

Laboratory Analyses

Prior to analyses, whole soil samples were dried at $35^{\circ} \mathrm{C}$ for 3 to 4 days and then ground by hand to pass a $2.0 \mathrm{~mm}$ sieve. Identifiable plant material $(>2.0 \mathrm{~mm}$ in diameter, $>10 \mathrm{~mm}$ in length) was removed during sieving. Total soil $\mathrm{C}$ was determined by dry combustion on soil ground to pass a $0.106 \mathrm{~mm}$ sieve using a Carlo Erba NA $1500 \mathrm{CN}$ analyzer (Thermo Scientific, Waltham, MA, USA). Using the same fine-ground soil, inorganic $\mathrm{C}$ was measured on soils with a $\mathrm{pH} \geq 7.2$ by quantifying the amount of $\mathrm{CO}_{2}$ produced using a volumetric calcimeter after application of dilute $\mathrm{HCl}$ stabilized with $\mathrm{FeCl}_{2}$ [24]. Soil organic $\mathrm{C}$ was calculated as the difference 
Table 1 Location, climate, and soil attributes for sites included in study (listed by decreasing latitude)

\begin{tabular}{|c|c|c|c|c|}
\hline Site & MAP (mm) & MAT $\left({ }^{\circ} \mathrm{C}\right)$ & Prevalent soil type & Soil classification \\
\hline Munich, ND & 460 & 4.7 & Barnes-Buse loams, $3 \%$ to $6 \%$ slopes & $\begin{array}{l}\text { Fine-Loamy, Mixed, Superactive, Frigid Calcic } \\
\text { Hapludolls and Argiudolls }\end{array}$ \\
\hline Streeter, ND & 432 & 5.5 & Barnes-Svea loams, $0 \%$ to $6 \%$ slopes & $\begin{array}{l}\text { Fine-loamy, Mixed, Superactive, Frigid Calcic and } \\
\text { Pachic Hapludolls }\end{array}$ \\
\hline Bristol, SD & 559 & 5.6 & $\begin{array}{l}\text { Forman-Buse-Aastad loams, } 2 \% \text { to } \\
9 \% \text { slopes }\end{array}$ & $\begin{array}{l}\text { Fine-Loamy, Mixed, Superactive, Frigid Calcic and } \\
\text { Pachic Argiudolls }\end{array}$ \\
\hline Highmore, SD & 538 & 8.7 & $\begin{array}{l}\text { Glenham-Prosper loams, } 2 \% \text { to } 6 \% \\
\text { slopes }\end{array}$ & $\begin{array}{l}\text { Mixed, Superactive, Mesic Typic and Pachic } \\
\text { Argiustolls }\end{array}$ \\
\hline Huron, SD & 531 & 7.5 & Houdek-Prosper loams, $2 \%$ to $6 \%$ slopes & $\begin{array}{l}\text { Fine-Loamy, Mixed, Superactive, Mesic Typic and } \\
\text { Pachic Argiustolls }\end{array}$ \\
\hline Ethan, SD & 577 & 9.1 & Houdek-Prosper loams, $0 \%$ to $2 \%$ slopes & $\begin{array}{l}\text { Fine-Loamy, Mixed, Superactive, Mesic Typic and } \\
\text { Pachic Argiustolls }\end{array}$ \\
\hline Crofton, NE & 704 & 9.3 & $\begin{array}{l}\text { Crofton-Nora complex, } 6 \% \text { to } 11 \% \text { - } \\
\text { slopes, eroded }\end{array}$ & $\begin{array}{l}\text { Fine-Silty, Mixed, Superactive, Calcareous, Mesic } \\
\text { Udic Ustorthents and Fine-Silty, Mixed, Superactive, } \\
\text { Mesic Udic Haplustolls }\end{array}$ \\
\hline Atkinson, NE & 625 & 9.1 & Dunn loamy sand, $0 \%$ to $3 \%$ slopes & $\begin{array}{l}\text { Sandy Over Loamy, Mixed, Superactive, Mesic } \\
\text { Oxyaquic Haplustolls }\end{array}$ \\
\hline Douglas, NE & 777 & 10.6 & $\begin{array}{l}\text { Wymore silty clay, } 2 \% \text { to } 7 \% \text { slopes, } \\
\text { eroded }\end{array}$ & Fine, Smectitic, Mesic Aquertic Argiudolls \\
\hline Lawrence, NE & 668 & 10.0 & Hastings silt loam, $1 \%$ to $3 \%$ slopes & Fine, Smectitic, Mesic Udic Argiustolls \\
\hline
\end{tabular}

MAP mean annual precipitation, MAT mean annual temperature

between total $\mathrm{C}$ and inorganic $\mathrm{C}$. Gravimetric data were converted to a volumetric basis for each sampling depth using field measured soil bulk density, which was determined using the oven-dry weight and known volume of the composited samples [5]. All data were expressed on an oven-dry basis.

Biomass samples were ground to pass a $1 \mathrm{~mm}$ screen prior to $\mathrm{C}$ determination by near infrared spectrophotometry (NIRS) [34]. A switchgrass NIRS prediction equation was based on total $\mathrm{C}$ analyses of a set of 108 switchgrass samples using combustion analysis [41]. The NIRS standard error of calibration and prediction for biomass $\mathrm{C}$ were 2.13 and $3.95 \mathrm{~g} \mathrm{~kg}^{-1}$, respectively.

\section{Statistical Analyses}

Changes in SOC between sampling times were calculated by subtracting initial values from values after 5 years within a sampling location. Calculated changes were then evaluated within a site by depth using a paired $t$-test in PROC MIXED [22]. Changes in SOC over time for cumulative sampling depths $(0-30$ and $0-120 \mathrm{~cm})$ within and across sites were evaluated similarly.

\section{Results}

Soil organic $\mathrm{C}$ changed in response to switchgrass biomass production at all sites within a 5 year period (Table 2). Soil organic $\mathrm{C}$ generally increased across sites; only at Huron and
Ethan were significant SOC decreases observed. Soil bulk density decreased significantly in near-surface depths at Huron and Ethan, contributing to decreased SOC. Changes in SOC across sites were most prevalent at $0-5$ and $20-30 \mathrm{~cm}$. No significant changes in SOC were observed at 10-20 cm. Of the 52 site-depths evaluated, increases in SOC over 5 years exceeded $2 \mathrm{MgC} \mathrm{ha}^{-1}$ in 18 site-depths, while increases $>5 \mathrm{Mg} \mathrm{Cha}{ }^{-1}$ were observed in six site-depths. Gravimetric and volumetric expressions of changes in SOC were correlated $(r=0.55 ; P<0.01)$, as were changes in SOC (volumetric) and soil bulk density $(r=0.51 ; P<0.01)$.

Sites at Streeter, Highmore, Atkinson, and Lawrence exhibited significant increases in SOC when summed over the 30 or $120 \mathrm{~cm}$ sampling depths (Fig. 2). Soil organic $\mathrm{C}$ accrual rates for responsive sites ranged from $0.8-1.2 \mathrm{Mg}$ $\mathrm{C} \mathrm{ha}{ }^{-1}$ year $^{-1}$ for the $0-30 \mathrm{~cm}$ depth. The only site with a significant increase in SOC over the $120 \mathrm{~cm}$ sampling depth was Lawrence, with an accrual rate of $3.8 \mathrm{Mg} \mathrm{C}^{-1}$ year $^{-1}$. Across sites, SOC increased significantly at $0-$ $30 \mathrm{~cm}(P=0.03)$ and $0-120 \mathrm{~cm}(P=0.07)$ (Fig. 2). Rates of SOC accrual across sites were 1.1 and $2.9 \mathrm{Mg} \mathrm{C} \mathrm{ha}^{-1}$ year $^{-1}$ for the $0-30$ and $0-120 \mathrm{~cm}$ depths, respectively. No significant associations were observed between annual change in SOC at $0-30 \mathrm{~cm}$ and relevant edaphic and climatic attributes (data not shown).

Harvested aboveground $\mathrm{C}$ averaged $2.5 \pm 0.7 \mathrm{Mg} \mathrm{C}$ ha $^{-1}$ over a 5 year period across all ten farms (Figs. 2 and 3). Increased biomass yields contributed to greater harvested aboveground $\mathrm{C}$ over time, which peaked in the 
Table 2 Change in soil bulk density and soil organic $\mathrm{C}$ at each site after 5 years under switchgrass

\begin{tabular}{|c|c|c|c|c|c|c|c|}
\hline \multirow[b]{2}{*}{ Site } & \multicolumn{7}{|c|}{ Soil depth (cm) } \\
\hline & $0-5$ & $5-10$ & $10-20$ & $20-30$ & $30-60$ & $60-90$ & $90-120$ \\
\hline & \multicolumn{7}{|c|}{ Soil bulk density $\left(\mathrm{Mg} \mathrm{m}^{-3}\right)$} \\
\hline Munich, ND & $-0.17 * *$ & -0.04 & 0.00 & $0.07 * *$ & - & - & - \\
\hline Streeter, ND & $-0.08 * *$ & -0.05 & -0.05 & -0.06 & - & - & - \\
\hline Bristol, SD & $0.07 *$ & 0.06 & 0.05 & $0.13^{* *}$ & - & - & - \\
\hline Highmore, SD & -0.30 & -0.09 & $-0.06 * *$ & 0.03 & - & - & - \\
\hline Huron, SD & $-0.42 * *$ & -0.04 & $-0.06^{* *}$ & -0.01 & - & - & - \\
\hline Ethan, SD & $-0.20 * *$ & -0.06 & -0.06 & 0.05 & - & - & - \\
\hline Crofton, NE & $0.25 * *$ & $0.10^{* *}$ & $0.03 *$ & $0.09 * *$ & $0.14 * *$ & -0.01 & $-0.09 *$ \\
\hline Atkinson, NE & $0.14^{*}$ & 0.18 & 0.04 & 0.04 & - & - & - \\
\hline Douglas, NE & $0.23 * *$ & $0.10^{*}$ & 0.00 & 0.09 & 0.06 & $0.10^{* *}$ & $0.03 *$ \\
\hline \multirow[t]{2}{*}{ Lawrence, NE } & 0.00 & -0.01 & $0.07 *$ & 0.05 & 0.04 & 0.01 & -0.02 \\
\hline & \multicolumn{7}{|c|}{ Soil organic $\mathrm{C}\left(\mathrm{g} \mathrm{C} \mathrm{kg}^{-1}\right)$} \\
\hline Munich, ND & 4.7 & $2.6^{*}$ & 4.3 & 0.8 & - & - & - \\
\hline Streeter, ND & 1.8 & 1.4 & 1.9 & $5.4^{* *}$ & - & - & - \\
\hline Bristol, SD & $2.6^{*}$ & 2.3 & 2.0 & 6.7 & - & - & - \\
\hline Highmore, SD & $7.8^{* *}$ & 0.3 & 2.5 & $3.8^{* *}$ & - & - & - \\
\hline Huron, SD & -2.1 & -0.9 & 0.9 & 2.4 & - & - & - \\
\hline Ethan, SD & $1.9^{* *}$ & $-1.2 * *$ & -0.4 & -0.4 & - & - & - \\
\hline Crofton, NE & 0.0 & -1.1 & -0.7 & 0.6 & 0.8 & -0.6 & 0.1 \\
\hline Atkinson, NE & 0.0 & 1.8 & 1.1 & 0.3 & - & - & - \\
\hline Douglas, NE & 1.1 & -0.2 & -0.3 & -0.1 & 0.8 & 1.3 & 0.3 \\
\hline \multirow[t]{2}{*}{ Lawrence, NE } & 2.1 & 0.5 & 0.7 & $1.0^{* *}$ & $0.8^{* *}$ & $1.3^{* *}$ & $1.4^{* *}$ \\
\hline & \multicolumn{7}{|c|}{ Soil organic $\mathrm{C}\left(\mathrm{Mg} \mathrm{C} \mathrm{ha}{ }^{-1}\right)$} \\
\hline Munich, ND & 0.31 & 1.19 & 5.37 & 1.51 & - & - & - \\
\hline Streeter, ND & -0.54 & -0.10 & 0.83 & $4.01 * *$ & - & - & - \\
\hline Bristol, SD & $2.52 *$ & $2.21^{*}$ & 3.97 & 12.97 & - & - & - \\
\hline Highmore, SD & 0.55 & -0.76 & 1.69 & $5.23 * *$ & - & - & - \\
\hline Huron, SD & $-5.28 * *$ & -1.06 & 0.35 & 3.32 & - & - & - \\
\hline Ethan, SD & -0.75 & $-1.23 * *$ & -1.29 & 0.05 & - & - & - \\
\hline Crofton, NE & $2.32 * *$ & 0.16 & -0.51 & $1.70^{*}$ & 6.19 & -2.77 & -0.79 \\
\hline Atkinson, NE & 0.77 & $2.20 * *$ & 2.01 & 0.74 & - & - & - \\
\hline Douglas, NE & $3.38 * *$ & 0.82 & -0.25 & 1.19 & 5.04 & 6.71 & 1.51 \\
\hline Lawrence, NE & 1.32 & 0.28 & 1.53 & $1.55^{* *}$ & $3.62 * *$ & $5.24 * *$ & 5.29 \\
\hline
\end{tabular}

${ }^{*} P \leq 0.1$ (change from initial sampling significant); ${ }^{* *} P \leq 0.05$ (change from initial sampling significant)

fourth year at $3.7 \pm 0.8 \mathrm{Mg} \mathrm{C} \mathrm{ha}^{-1}$ (Fig. 3). Variation in harvested $\mathrm{C}$ was largely due to variation in biomass yield, as variation in biomass $\mathrm{C}$ concentration was limited (Biomass $\mathrm{C}_{\text {Mean }}=444.1 \pm 6.1 \mathrm{~g} \mathrm{C} \mathrm{kg}^{-1}$, Biomass $\mathrm{C}_{\text {Range }}=425-454 \mathrm{~g}$ $\mathrm{C} \mathrm{kg}^{-1}$ ). Weather conditions as well as deviations from recommended management practices contributed to variation in biomass yield across sites [32]. Full biomass yield potential of switchgrass often is not achieved until one to two growing seasons following establishment. However, once mature, switchgrass stands have been shown to produce consistent biomass yields over time [9]. Harvested aboveground $\mathrm{C}$ was positively correlated with annual change in SOC at $0-30 \mathrm{~cm}$, though the relationship was weak (Harvested $\mathrm{C}_{\text {Mean }}, r=0.50 ; P=0.14$ ). Annual change in SOC was more strongly associated with mean and maximum aboveground biomass hand-clipped from quadrants located throughout each field (Yield $\mathrm{Mean}_{\text {, }} r=0.68, P<0.05$; Yield ${ }_{\text {Max }}$, $r=0.77, P<0.01)$.

\section{Discussion}

The capacity of perennial grasses to affect change in soil properties over time is well documented [10], but information specific to switchgrass managed for bioenergy production is limited. In this study, switchgrass significantly affected change in SOC, a parameter known to respond slowly to changes in management in semiarid agro-ecosystems [27]. In addition to the relatively rapid response, change in SOC was detected on working farms, where spatial variation and potential measurement errors can increase the minimum detectable change in SOC over time. 
Fig. 2 Aboveground biomass $\mathrm{C}$ and change in soil organic $\mathrm{C}$ (SOC) over 5 years at $0-30$ and $0-120 \mathrm{~cm}$ for sites included in study. a Results within and across ten sites sampled to 0 $30 \mathrm{~cm}$ depth. Results from Atkinson site based on 4 year switchgrass stand. b Results within and across three sites sampled to $120 \mathrm{~cm}$ depth. Change in $\mathrm{SOC} \pm 1$ standard error along with the $P$-value for change in SOC over time is provided within and across sites

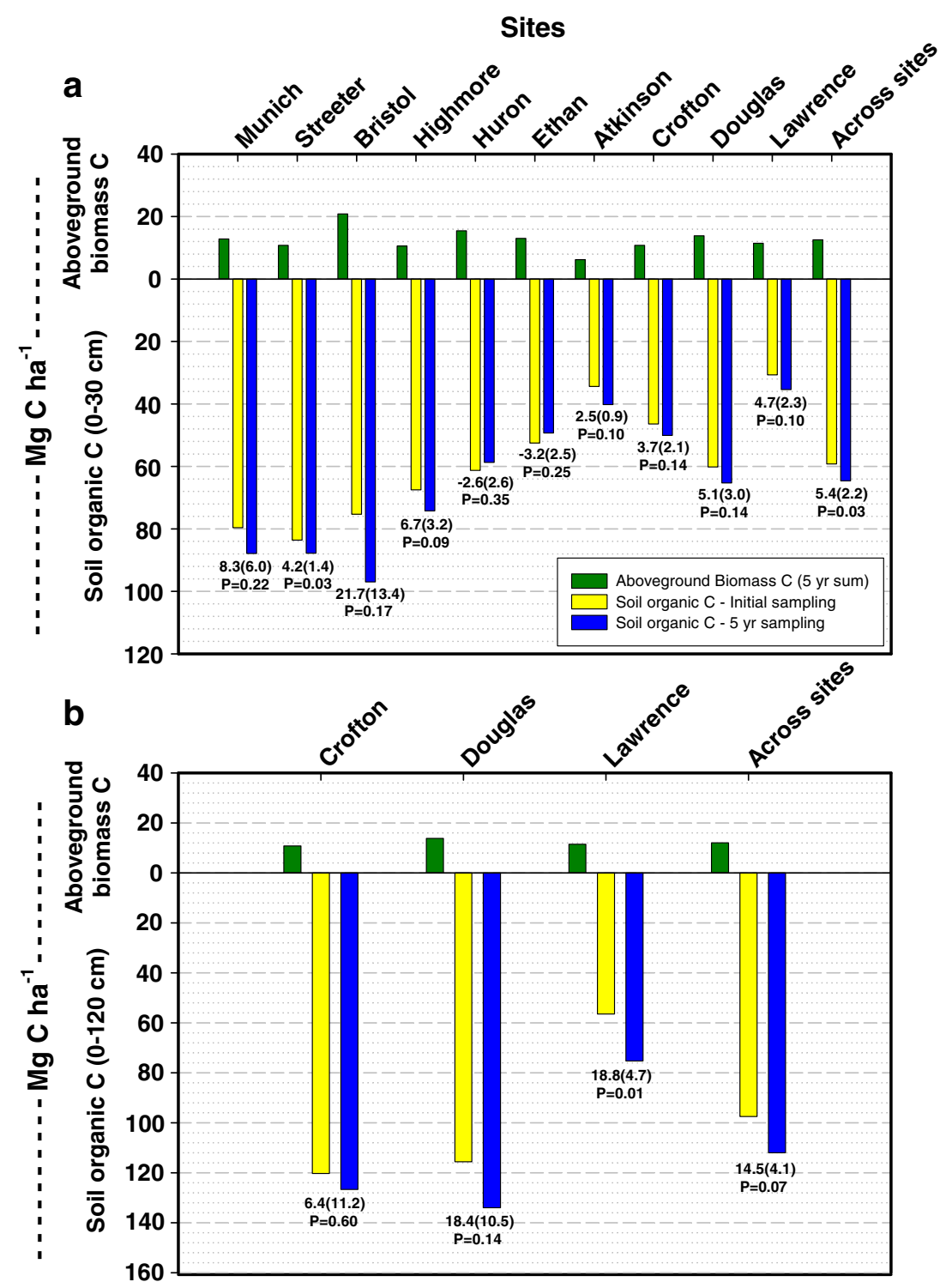

Increases in SOC under switchgrass were likely caused by belowground $\mathrm{C}$ input from root biomass and rhizodeposition [11,45] and decreased soil organic matter losses by erosion [6]. Research conducted by ecologist John Weaver and his graduate students over 60 year ago provide ancillary support for increased SOC under switchgrass [35, 42, 43]. Their detailed surveys of prairie grass roots indicated switchgrass to have the deepest root system of all grasses examined, with roots extending to a soil depth of $3 \mathrm{~m}$ [42]. This finding, coupled with observations that prairie grass roots regenerate by replacing dying roots with new, live roots [43] indicates the potential for significant $\mathrm{C}$ input to the soil under switchgrass.

Depth distribution of increased SOC has relevance to nutrient conservation, water infiltration, and erosion control [12]. Potential improvements in near-surface soil functions resulting from increased SOC are particularly important

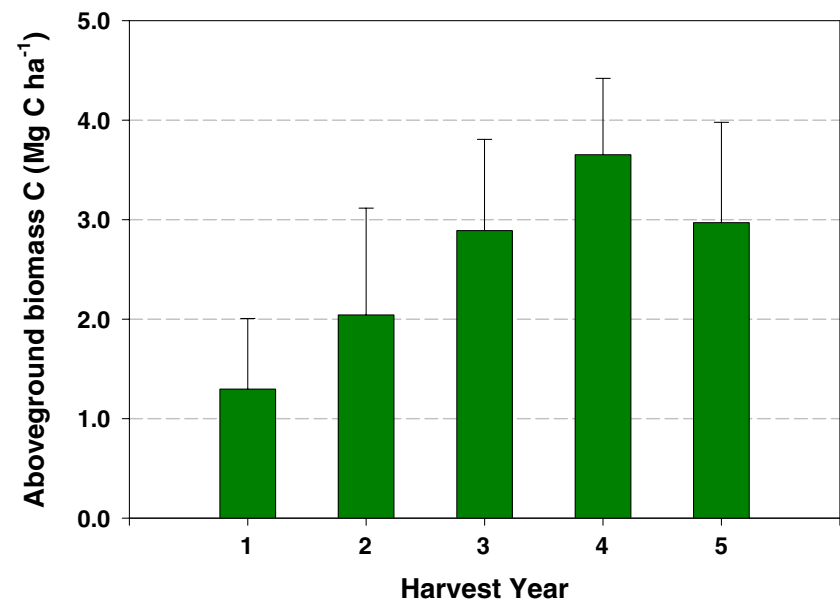

Fig. 3 Aboveground biomass $\mathrm{C}$ across sites for each year of study, \pm 1 standard error 
should switchgrass be included as a perennial phase in cropping systems, as these attributes would be expected to enhance crop productivity following the transition to annual cropping [7]. Accordingly, increases in SOC below the microbially-active surface horizon act to enhance the role of soil as a repository for atmospheric $\mathrm{C}$, as mineralization and loss of $\mathrm{C}$ decreases with increasing depth. Increased SOC under switchgrass at depths below $30 \mathrm{~cm}$ is common, having been observed in other studies in the northern Great Plains $[11,18,20]$. In contrast to the assumptions made recently [33], it is likely much of the carbon sequestered during switchgrass production would be conserved because plowing is no longer necessary to rotate from pasture grasses to grain crops and back again because of advances in no-till technology. The same technology can be applied to switchgrass grown for bioenergy [28].

Accrual rates of SOC under switchgrass contribute significantly to its potential to provide a favorable net GHG balance [8, 32]. Though inclusive GHG flux field assessments of switchgrass are lacking, SOC accrual rates under switchgrass appear — in this, and other related studies [18] — large enough to easily offset nitrous oxide $\left(\mathrm{N}_{2} \mathrm{O}\right)$ emissions. Greenhouse gas flux measurements from fertilized perennial grasses support this notion. Annual $\mathrm{N}_{2} \mathrm{O}$ emission from a crested wheatgrass pasture fertilized with synthetic $\mathrm{N}$ was found to be $3.4 \mathrm{~kg} \mathrm{~N}$ $\mathrm{ha}^{-1}$ year $^{-1}$ [19], equating to $1.6 \mathrm{Mg} \mathrm{CO}_{2} \mathrm{e} \mathrm{ha}{ }^{-1}$ year $^{-1}$, or approximately $40 \%$ of the $\mathrm{C}$ sequestration rate at $0-30 \mathrm{~cm}$ observed across sites in this study. Methane $\left(\mathrm{CH}_{4}\right)$ flux contributions to net GHG emission from switchgrass would likely be negligible, as perennial grasses in semiarid regions are a minor sink for atmospheric $\mathrm{CH}_{4}$ [21]. Field-based assessments of both $\mathrm{N}_{2} \mathrm{O}$ and $\mathrm{CH}_{4}$ flux are urgently needed to assign greater confidence to estimates of net GHG emission for switchgrass.

U.S. federal law [39] will require renewable biofuels to meet certain GHG emission reductions from conventional gasoline using LCAs. Accordingly, data generated in this study should prove useful for scientists and policy makers conducting and/or using LCAs of bioenergy production systems. Previous LCAs including switchgrass production for biomass energy have utilized $\mathrm{C}$ offset rates four- to 11-fold lower than the $\mathrm{C}$ sequestration rates observed in this study $[1,32,33]$. It is important to acknowledge, however, LCAs have included GHG emissions associated with fertilizer and machinery use (e.g., GREET-derived C offset) [44], which would act to decrease net $\mathrm{C}$ offsets. Furthermore, LCAs generally calculate $\mathrm{C}$ sequestration over 30 or 100 year time periods, during which time the soil $\mathrm{C}$ accrual rate would be expected to plateau [2].

Results from this study underscore the importance of LCAs to account for inter- and intra-site variability inherent to key input parameters such as SOC. Variability in SOC change across sites within the studied agro-ecoregion was significant, from -0.6 to $4.3 \mathrm{Mg} \mathrm{C}^{-1}$ year $^{-1}$ for the $0-30 \mathrm{~cm}$ depth. Similar variation would likely exist in other agro-ecoregions. Accordingly, LCAs should acknowledge this variability by including confidence intervals in addition to means for estimating the effects of agricultural production practices on the environment.

Research conducted on working farms can provide critical information regarding agroecosystem effects on agronomic and environmental performance under conditions not available at research stations [23]. Placement of studies on working farms, however, has drawbacks. As an example, farmers in this study participated via a 5 year contract. It was not feasible to extend the contract for an array of reasons that differed with each farmer. Yet measurement of SOC change under switchgrass beyond 5 year represents a critical research need in order to quantify GHG balance over the long-term. Such a situation highlights the need for an expansion of the Long Term Ecological Research (LTER) Network to sites devoted to evaluation of agricultural production systems [25]. Agriculture is now being asked to supply food, feed, fiber, and energy for a growing population. Because of the potentially large positive or negative effects associated with the added requirements of energy production within agro-ecosystems, expansion of Agricultural LTER sites in major agro-ecoregions needs to be seriously considered for monitoring environmental effects over the long-term.

Acknowledgments We gratefully acknowledge the farmers who participated in the study. We also thank Jamie Erhardt, Danielle Forre, Jason Gross, Steve Masterson, Steven Petrik, Gail Sage, Travis Schulz, Nate Shilman, Nick Shilman, Becky Wald, Danny Wikenheiser, and Alexa Zink for providing excellent technical support during sampling, processing, and laboratory analyses. Initial funding for the research was provided by U.S. Department of Energy Biomass Feedstock Program, Oak Ridge National Laboratory, contract no. DE-A105-900R2194. The U.S. Department of Agriculture, Agricultural Research Service, is an equal opportunity/affirmative action employer and all agency services are available without discrimination. Mention of commercial products and organizations in this manuscript is solely to provide specific information. It does not constitute endorsement by USDA-ARS over other products and organizations not mentioned. This evaluation contributed to two USDA-ARS cross-location research efforts: GRACEnet (Greenhouse Gas Reduction through Agricultural Carbon Enhancement Network) and REAP (Renewable Energy Assessment Project).

Open Access This article is distributed under the terms of the Creative Commons Attribution Noncommercial License which permits any noncommercial use, distribution, and reproduction in any medium, provided the original author(s) and source are credited.

\section{References}

1. Adler PR, Del Grosso SJ, Parton WJ (2007) Life-cycle assessment of net greenhouse-gas flux for bioenergy cropping systems. Ecol Appl 17(3):675-691 
2. Andress D (2002) Soil carbon changes for bioenergy crops. Agronne National Laboratory, US Department of Energy, Argonne, IL 2F-00921

3. Bailey RG (1995) Description of the ecoregions of the United States, 2nd edn. USDA, Forest Service, US Government Printing Office, Washington DC, Miscellaneous Publication 1391

4. Berdahl JD et al (2005) Biomass yield, phenology, and survival of diverse switchgrass cultivars and experimental strains in western North Dakota. Agron J 97:549-555

5. Blake GR, Hartge KH (1986) Bulk density. In: Klute A (ed) Methods of soil analysis. Soil Science Society of America, Madison, WI, pp 363-382

6. Dabney SM, Shields FD Jr, Temple DM, Langendoen EJ (2004) Erosion processes in gullies modified by establishing grass hedges. Trans ASAE 47(5):1561-1571

7. Entz MH, Baron VS, Carr PM, Meyer DW, Smith SR Jr, McCaughey WP (2002) Potential of forages to diversify cropping systems in the northern Great Plains. Agron J 94:240-250

8. Fargione J, Hill J, Tilman D, Polasky S, Hawthorne P (2008) Land clearing and the biofuel carbon debt. Science 319:1235-1238

9. Fike JH et al (2006) Long-term yield potential of switchgrass-forbiofuel systems. Biomass Bioenergy 30:198-206

10. Follett RF, Pruessner EG, Samson-Liebig SE, Kimble JM, Waltman SW (2001) Carbon Sequestration under the CRP in the Historic Grassland Soils in the USA. In: Lal R (ed) Soil carbon sequestration and the greenhouse effect. SSSA, Madison, WI, pp $27-40$

11. Frank AB, Berdahl JD, Hanson JD, Liebig MA, Johnson HA (2004) Biomass and carbon partitioning in switchgrass. Crop Sci 44:1391-1396

12. Franzluebbers AJ (2002) Soil organic matter stratification ratio as an indicator of soil quality. Soil Tillage Res 66:95-106

13. Garten CT Jr, Wullschleger SD (2000) Soil carbon dynamics beneath switchgrass as indicated by stable isotope analysis. J Environ Qual 29:645-653

14. Gomez KA (1984) Statistical procedures for agricultural research, 2nd edn. Wiley, New York

15. Hanson JD, Johnson HA (2005) Germination of switchgrass under various temperature and $\mathrm{pH}$ regimes. Seed Tech 27(2):203-210

16. Hill J, Nelson E, Tilman D, Polasky S, Tiffany D (2006) Environmental, economic, and energetic costs and benefits of biodiesel and ethanol biofuels. Proc Natl Acad Sci U S A 103 (30): 11206-11210

17. Jones CA (1983) Effect of soil texture on critical bulk densities for root growth. Soil Sci Soc Am J 47:1208-1211

18. Lee DK, Owens VN, Doolittle JJ (2007) Switchgrass and soil carbon sequestration response to ammonium nitrate, manure, and harvest frequency on Conservation Reserve Program land. Agron J 99:462-468

19. Liebig et al (2006) Soil response to long-term grazing in the northern Great Plains of North America. Agric Ecosys Environ 115:270-276

20. Liebig MA, Johnson HA, Hanson JD, Frank AB (2005) Soil carbon under switchgrass stands and cultivated cropland. Biomass Bioenergy 28(4):347-354

21. Liebig et al (2005) Greenhouse gas contributions and mitigation potential of agricultural practices in northwestern USA and western Canada. Soil Tillage Res 83:25-52

22. Littell RC, Milliken GA, Stroup WW, Wolfinger RD (1996) SAS system for mixed models. SAS Inst, Cary, NC

23. Lockeretz W, Anderson MD (1993) Agricultural research alternatives. University of Nebraska Press, Lincoln, NE
24. Loeppert RH, Suarez DL (1996) Carbonate and gypsum. In: Sparks DL (ed) Methods of soil analysis. Soil Science Society of America, Madison, WI, pp 437-474

25. LTER (2008) The U.S. Long Term Ecological Research Network. ONLINE http://www.lternet.edu (19 June 2008)

26. McLaughlin SB et al (2002) High-value renewable energy from prairie grasses. Environ Sci Tech 36(10):2122-2129

27. Mikha MM et al (2006) Cropping system influences on soil chemical properties and soil quality in the Great Plains. Renew Agric Food Sys 20(1):26-35

28. Mitchell RB, Vogel KP, Anderson BE, McAndrew TJ (2005) Renovating pastures with glyphosate tolerant soybeans. Online. Forage and Grazinglands. doi:10.1094/FG-2005-0428-01-BR

29. Perrin K, Vogel K, Schmer M, Mitchell R (2008) Farm-scale production cost of switchgrass. Bioenergy Res 1:91-97, doi:10.1007/s12155-008-9005-y

30. Scharlemann JPW, Laurance WF (2008) How green are biofuels? Science 319:43-44

31. Schmer MR et al (2006) Establishment stand thresholds for switchgrass grown as a bioenergy crop. Crop Sci 46:157-161

32. Schmer MR, Vogel KP, Mitchell RB, Perrin RK (2008) Net energy of cellulosic ethanol from switchgrass. Proc Natl Acad Sci USA 105(2):464-469

33. Searchinger $T$ et al (2008) Use of U.S. croplands for biofuels increases greenhouse gases through emissions from land use change. Science 319:1238-1240

34. Shenk JS, Westerhaus MO (1991) Population definition, sample selection, and calibration procedures for near infrared reflectance spectroscopy. Crop Sci 31:469-474

35. Shively SB, Weaver JE (1939) Amount of underground plant material in different grassland climates. Neb Conserv Bull 21:168, Conservation and Survey Division, University of Nebraska, Lincoln, NE

36. Tilman D, Hill J, Lehman C (2006) Carbon-negative biofuels from low-input high-diversity grassland biomass. Science 314:1598-1600

37. USDA (USDA Soil Survey Division Staff) (1993) Soil survey manual. US Department of Agriculture Handbook No. 18. US Department of Agriculture, US Government Printing Office, Washington, DC

38. USDA-NRCS (USDA-NRCS Soil Survey Staff) (1999) Soil taxonomy: a basic system of soil classification for making and interpreting soil surveys, 2nd edn. Agriculture Handbook No. 436. US Department of Agriculture, US Government Printing Office, Washington, DC

39. US House. 110th Congress, 1 st Session. HR 6. Energy Independence and Security Act of 2007. Online. GPO Access. Available: http://www.gpoaccess.gov/bills/index.html (21 March 2008)

40. Walsh ME (1998) U.S. bioenergy crop economic analyses: status and needs. Biomass Bioenergy 14:341-350

41. Watson ME, Isaac RA (1990) Analytical instruments for soil and plant analysis. In: Westerman RL (ed) Soil testing and plant analysis. Soil Science Society of America, Madison, WI, pp 691-740

42. Weaver JE (1968) Prairie plants and their environments: a fifty year study in the Midwest. University of Nebraska Press, Lincoln, NE

43. Weaver JE, Zink E (1946) Length of life of roots of ten species of perennial range and pasture grasses. Plant Physiol 21:201-217

44. Wu M, Wu Y, Wang M (2006) Energy and emission benefits of alternative transportation liquid fuels derived from switchgrass: a fuel life cycle assessment. Biotechnol Prog 22:1012-1024

45. Zan CS, Fyles JW, Girouard P, Samson RA (2001) Carbon sequestration in perennial bioenergy, annual corn and uncultivated systems in southern Quebec. Agric Ecosys Environ 86:135-144 